\title{
Beta cell
}

National Diabetes Information Clearinghouse (NDIC)

\section{Definitions}

\section{Pancreas}

Defined by National Diabetes Information Clearinghouse (NDIC)

Insulin

Defined by National Diabetes Information Clearinghouse (NDIC)

\section{Source}

National Diabetes Information Clearinghouse (U.S.). (2009). The diabetes dictionary. [Bethesda, Md.]: U.S. Dept. of Health and Human Services, National Institutes of Health, National Institute of Diabetes and Digestive and Kidney Diseases, National Diabetes Information Clearinghouse.

A cell that makes insulin. Beta cells are located in the islets of the pancreas. 